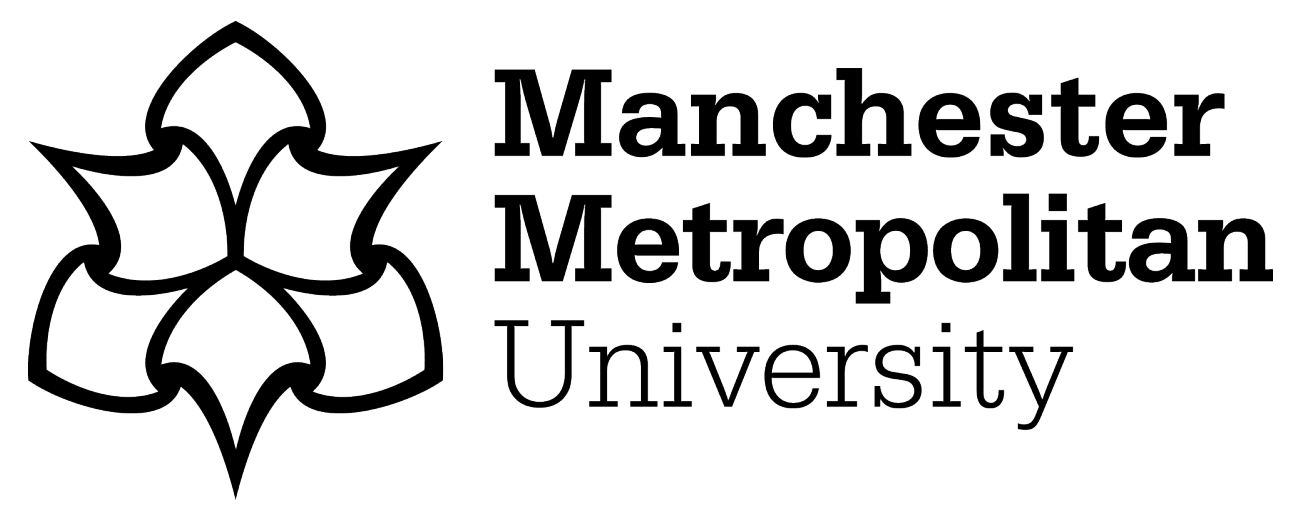

Dewick, P and Foster, C (2017) Focal Organisations and Eco-innovation in Consumption and Production Systems. Ecological Economics, 143. pp. 161169. ISSN 0921-8009

Downloaded from: https://e-space.mmu.ac.uk/621871/

Version: Accepted Version

Publisher: Elsevier

DOI: https://doi.org/10.1016/j.ecolecon.2017.07.012

Usage rights: Creative Commons: Attribution-Noncommercial-No Derivative Works 4.0

Please cite the published version 


\title{
Focal organisations and eco-innovation in consumption and production systems
}

Paul Dewick* and Chris Foster**

*Manchester Institute of Innovation Research, Alliance Manchester Business School, The University of Manchester

** Eugeos Ltd.

Corresponding author: paul.dewick@manchester.ac.uk

Forthcoming in 2018 in Ecological Economics

\begin{abstract}
This paper explores the role of 'focal organisations' in stimulating eco-innovation at the locus of greatest environmental impacts within a consumption and production system (CPS). Focal organisations by definition have considerable power in these systems. We combine insights from the innovation studies literature with the sustainable/green supply chain literature to explore how focal organisations exercise this power in pursuit of system-wide sustainability. Through a case study of the milk CPS in the UK, we illustrate different strategies of the focal organisations to stimulate incremental eco-innovation along existing trajectories. We also show how, despite focal organisation support, radical eco-innovation is inhibited by inherent path dependencies and other institutional dimensions of the CPS. By demonstrating the complementarities of positioning the case study findings within two synergistic literatures, this paper contributes theoretically by extending and elaborating ecoinnovation studies. It also has a practical utility for policy makers seeking to chart a path to more sustainable CPS by relying on focal organisations.
\end{abstract}

\section{Highlights}

- Explores how focal actors stimulate eco-innovation in consumption/production systems

- Combines innovation systems and sustainable/green supply chain management literatures

- Extends and elaborates our understanding of the dynamics of eco-innovation at the systems level...

- ....and strategies of individual organisations toward system wide sustainability. 
Key words: eco-innovation, innovation systems, sustainable/green supply chain management, focal organisations

\section{Introduction}

One of the UN's sustainable development goals for 2030 is to ensure sustainable Consumption and Production Systems (CPS) (UN, 2015). A CPS encompasses all activities transforming energy and basic resources into a particular good or service, distributing it to users, its use and (in some cases) its eventual management as waste. For Lebel and Lorek (2008:244), a sustainable CPS is one in which the "transformation of energy and materials maintains or improves human well-being (or utility) without irreversibly reducing the environmental resources". Previous studies have shown that eco-innovation (Rennings, 2000), in particular radical eco-innovation, has a crucial role in contributing to more sustainable CPS (Boons and Wagner, 2009; CarrilloHermosilla et al. 2010; Vergragt et al., 2013). Other studies have found that collaboration between organisations is a significant determinant of successful ecoinnovation initiatives (De Marchi, 2012; Cainelli et al., 2016). The eco-innovation activities of organisations are very much in the foreground of a sustainable CPS.

The dynamics of eco-innovation within CPS have often been studied from an innovation systems perspective (van den Bergh et al., 2011; Vergragt et al., 2013), helping us understand the long-term co-evolution and co-dependency between actors, networks and institutions, and sustainable change at a bounded systems level. However, system level analyses are limited in the extent to which they allow the researcher to explore in depth how individual organisations can collaborate with others to stimulate eco-innovation at parts of the CPS where environmental impacts are highest. The sustainable/green supply chain literature offers more sophisticated insights into how individual organisations can manage relations with suppliers to pursue higher environmental performance (Seuring and Muller, 2008; Carter and Rogers, 2008). The definition of a sustainable/green supply chain is close to (but more linear than) the conceptualisation of a sustainable CPS (Roscoe et al., 2016) ${ }^{1}$, but the literature is often vague about how individual organisations strategically stimulate

\footnotetext{
${ }^{1}$ Sustainable supply chain networks are closer to the concept of a CPS (Roscoe et al., 2016)
} 
either incremental or radical eco-innovation (Mylan et al., 2015; Roscoe et al., 2016), and there is little appreciation of how these strategies are affected by the evolutionary and co-dependent characteristics of the CPS.

By combining evolutionary insights from the innovation systems literature with strategic insights from the sustainable/green supply chain management literature, this paper aims to understand better the collaborative strategies of individual organisations to stimulate eco-innovation and contribute to more sustainable CPS. We focus on how organisations (referred to as 'focal organisations' by virtue of their buying power and position in the CPS) can, given the commitment to do so, stimulate eco-innovation at stages of high environmental impact in the CPS. Informed by secondary review, semistructured interviews and many informal discussions within a single setting (a case study of the UK milk CPS) we demonstrate the complementarities of positioning a study of eco-innovation within two synergistic literatures.

Our case shows how focal organisations can strategically stimulate incremental ecoinnovation along established trajectories. The blending of innovation systems with sustainable/green supply chain management thinking raises questions, however, about the extent to which focal organisations can exert their influence to bring about more radical change in the CPS. This matters because although we know that the cumulative effect of incremental eco-innovation can be significant, the nature of incremental innovation does not match the urgency of the UN 2030 goal. This paper extends our understanding of the dynamics of eco-innovation the systems level and the strategies of individual organisations to exercise their power in pursuit of CPSwide sustainability. It responds to the call of Boons and Wagner (2009) for more research into inter-level linkages in studies of eco-innovation.

\section{Literature review}

Over the last twenty years, eco-innovation has been investigated widely. Despite multiple definitions, differences of opinion about whether intention matters, and mixed evidence of the determinants of eco-innovation, there is much agreement on the fundamentals. Eco-innovation essentially comprises new ideas, behaviours, products and processes, applied or introduced by actors, which contribute to a reduction of environmental burdens or to ecologically specified sustainability targets, relative to 
existing approaches (Rennings, 2000). As distinct from environmental innovation and conventional innovation, eco-innovation improves both environmental and economic performance (Ghisetti and Pontoni, 2015). Eco-innovations that significantly improve the environmental performance of goods or production processes are known as radical eco-innovations; eco-innovations with a smaller effect, often improving continuously the environmental performance of goods and extant processes along existing trajectories are known as incremental eco-innovations (Wagner and Llerena, 2011). Of the two types, studies show that incremental eco-innovations are more common than radical eco-innovations (Hellstrom, 2007); they are less risky, less uncertain, less costly. In contrast, radical eco-innovations are at odds with the incumbent system and must overcome economic, social and institutional lock-in (Carrillo-Hermosilla et al., 2010). By their very nature, radical innovations offer the best hope of more sustainable CPS emerging in the long term.

Eco-innovations stem from a social process within which many individuals and organisations participate (Boons and Wagner, 2009). In almost all CPS - except those dominated by vertically integrated organisations - eco-innovation requires collaboration between organisations. We know that knowledge and know-how are important inputs into the innovation process and there is evidence that for ecoinnovation the source of this knowledge and know-how tends to stem from outside the organisation (Horbach et al., 2013; Triguero et al., 2013; Ghisetti and Pontoni, 2015). Collaboration between organisations within CPS (e.g. customers, suppliers, competitors) and beyond (e.g. universities and public research centres; consultancies and private research centres) is crucial for eco-innovation (De Marchi, 2012; Cainelli et al. 2015; Bossle et al., 2016).

Analyses of how CPS become more sustainable have been approached from several vantage points (Vergragt et al., 2013). These have been mainly from an economic or sociological perspective of science and technology, rooted in the 'sectoral systems of innovation' (SSI) literature (Malerba, 2002), 'technological innovation systems' (TIS) literature (Carlsson and Stankiewicz, 1991) or 'socio-technical systems' (STS) literature (Geels and Schot, 2007). Whilst all three approaches differ in their treatment of changing system boundaries and the roles of actors (e.g. organisations, technologies), networks (e.g. energy and transport infrastructures; networks of 
knowledge diffusion) and institutions (e.g. formal institutions such as government policies, regulation, standards; informal institutions such as practices, life styles and behaviours) (Coenan and Diaz Lopez, 2011), all acknowledge the inter-dependence and co-evolution of these elements in creating new paths for innovation and constraining it to existing ones, shaping both the direction and pace of change in the system.

All three approaches have been used to study the dynamics of eco-innovation. The SSI approach, for example, has been employed to study the adoption and diffusion of eco-innovations in specific sectors, such as energy efficient technologies in the construction industry (Faber and Hoppe, 2012; Kiss et al., 2013). TIS has been used to study emerging eco-innovations such as carbon capture and storage (van Alphen et al., 2010; Lai et al., 2012), where it has proved useful in identifying the factors that facilitate (and hinder) the breakthrough of complex technologies. The STS approach has been widely used to study long-term transitions toward more sustainable systems such as energy (e.g. Yuan et al., 2012; Hansen and Nygaard, 2014; Haley, 2014). Innovation systems approaches help us understand the dynamics of sustainable transition at a CPS level: the long-term co-evolution and co-dependency between actors, networks and institutions, and sustainable change at a bounded systems level. However, with their focus on the systems level, they are more limited in analysing the role of agency and in particular the strategies of individual organisations for collaboration, which we noted earlier has a crucial bearing on the successful outcome of eco-innovation initiatives. To achieve a better understanding of the collaborative strategies used by individual organisations to stimulate eco-innovation and contribute to more sustainable CPS, we must look beyond the innovation systems literature. It has been acknowledged previously that exploring the connections between the systems and firm strategy levels enhances our understanding of both (Coriat and Weinstein, 2002; Boons and Wagner, 2009; Coenan and Diaz-Lopez, 2011; Flanagan et al., 2011). To that end, the sustainable/green supply chain literature offers some useful insights.

Sustainable supply chain management (encompassing green supply chain management) has been defined as the "management of material, information and capital flows as well as cooperation among companies along the supply chain while 
taking goals from all three dimensions of sustainability (economic, environmental and social) into account" (Seuring and Muller, 2008, p1700). Increasingly researchers have moved away from the simplistic, linear supply chain concept in favour of industrial supply networks (Roscoe et al., 2016), bringing the frame of analysis closer to the conceptualisation of a CPS. The sustainable/green supply chain literature is useful in identifying individual organisations able to stimulate eco-innovation at high environmental impact stages of the CPS, and unpacking the strategies they use. Seuring and Muller (2008, p1699) count 'focal' organisations as those that usually "rule or govern the supply chain... provide direct contact to the customer...and design the product or service offered". Similarly, Huber (2008, p1985) refers to 'focal' organisations as entities that can stimulate eco-innovation by virtue of their "unique position [in the CPS] in that they combine a high degree of supply power with an equally high degree of demand power". Likewise, for Leppelt et al. (2011, p1), focal organisations "own or govern a supply chain....[and].... rely on a complex, interconnected supply base" to improve the sustainability of the CPS. For van Bommel (2011) and Beske et al. (2013), notions of power, position and cooperation capabilities are key to focal organisation engagement in sustainable supply chain management strategies. The focal organisation's control over critical resources (e.g. brand name and reputation), its management of the innovation process, and its external orientation are also important (Gereffi, 1994; Gereffi et al., 2005; Henriques and Sharma, 2005; Vurro et al., 2009; van Bommel, 2011; Beske et al., 2013).

Analysis of how this power and influence manifests itself in specific strategies to stimulate eco-innovation is often more implicit than explicit in the sustainable/green supply chain literature. Huber (2008, p1985) ascribes 'focal power' to stimulating ecoinnovation upstream in CPS but does not detail the actions of focal organisations, save their ability to "effectively implement supply chain management". Leppelt et al. (2011) explain how focal organisations co-ordinate co-operative actions to improve sustainability performance across CPS using 'sustainable supplier relationship management' practices such as procurement, supplier audit and reporting. van Bommel (2011) proposes that powerful focal organisations will use 'offensive strategies'; that is, they develop new supply networks, and work collaboratively with a wide range of companies to develop more sustainable products. Beske et al. (2013) point to important 'collaborative, pro-active relationship management' practices such 
as 'technological integration' (enhanced communication and sharing of knowledge and information), 'logistic integration', 'joint development of products and processes' and 'reflexive control' (by which they mean routine performance evaluation). Although strategies for incremental and radical eco-innovation tend not to be referred to explicitly, one can draw parallels. For example, one can associate van Bommel's (2011) 'offensive' strategies with radical eco-innovation. Roscoe et al. (2016) are one exception. They argue that incremental innovations are more likely to stem from strategies that promote 'tight collaborations' with suppliers, allowing for knowledge and technology spillovers. They go on to argue that radical eco-innovations are more likely to stem from 'loose' (i.e. weak) ties between the focal organisation and suppliers, and strategies of the focal organisation to scan and select eco-innovations. Notwithstanding the sometimes vague connection to eco-innovation, missing from the sustainable/green supply chain literature is an appreciation of how the characteristics of the CPS affect the strategies of focal organisations to stimulate both incremental and radical eco-innovation. This is where an innovation systems perspective can add value.

In summary, whilst both the innovation systems and sustainable/green supply chain management literatures offer useful insights on their own, it is only when we bring together these synergistic literatures that we can develop a better understanding of the role of focal organisations to stimulate eco-innovation in CPS.

\section{Research method}

To understand better the collaborative strategies of focal organisations to stimulate eco-innovation and contribute to a more sustainable CPS, in this paper we combine evolutionary insights from the innovation systems literature with strategic insights from the sustainable/green supply chain literature. We follow a research strategy which focuses on understanding the dynamics present within a single case study setting (Eisenhardt, 1989). By demonstrating the 'complementarities' of positioning the case study within two synergistic literatures, we contribute to the extant literature by 'extending' (Ridder et al, 2012) and 'elaborating' (Ketokivi and Choi, 2014) the theory. Ridder et al (2012) argue that novel insights can follow by "more fully specifying existing theory...broadening a theoretical perspective" (ibid., p.376). 
George and Bennett (2005) argue that the choice of case study should be determined by its relevance to the research aim. Our interest is in exploring how specific organisations co-evolve with the CPS to develop focal power and then exercise this influence through strategies to stimulate eco-innovation. Mylan et al. (2015) provide a multiple case study of eco-innovation in the food chain and call for further research into the strategies of specific retailers and the consideration of radical eco-innovations. In this paper, we focus on the UK milk CPS and the focal role of large retailers to stimulate both incremental and radical eco-innovation. Fresh milk represents the single largest food category by sales value for most large retailers in the UK, and supply chains are now controlled by large retailers. Milk also represents the highest average cradle-to-retail greenhouse gas emissions of all grocery products (PSF, 2013). The vast majority of emissions in the UK milk CPS stem from pre-production (e.g. emissions associated with synthetic fertiliser production and application, and concentrate feed production) and primary production (e.g. enteric methane emissions from cattle and manure management) (Dewick et al., 2010, Figure 3.1, p.50). Liquid milk has been the subject of academic (Eide, 2002; Dewick et al., 2007; Dewick et al., 2010), policy (e.g. Foster et al. 2006; Foster et al., 2007) and industry (e.g. Dairy Supply Chain Forum, 2008; Forum for the Future, 2012) initiatives to reduce greenhouse gas emissions and address broader concerns about domestic food security, animal welfare and biodiversity. The co-evolution of the CPS and retailer in the context of a product with high environmental impacts over its life cycle impact, presents a relevant opportunity to explore how the focal organisation has stimulated eco-innovation in the CPS.

Case studies are rich empirical descriptions based on a variety of information sources (Yin, 2010). For this study, we combined semi-structured interviews with a thorough review of secondary material, a triangulation method of enquiry familiar to case study researchers (Evans, 2011). Based on our previous knowledge and experience in the industry, we developed an interview guide with a list of broad questions and probes to follow up responses and elicit greater detail from participants. We conducted an initial set of interviews with a group of individuals known to us and whose experience and expertise we considered important for providing insights into eco-innovation in the milk CPS. This approach is sometimes referred to as elite interviewing (conducted with those with "a body of knowledge or a degree of influence or a set of beliefs or opinions 
not otherwise held by or obtainable from, or embedded with less perceived influence or social importance than non-elites" (Vaughan 2011:109). We used these interviews to 'snow-ball' other knowledgeable informants. We interviewed organisations across the CPS and conducted several interviews with the organisations we consider focal: the large retailers (e.g. Tesco, ASDA). Altogether we conducted 18 semi-structured interviews with 23 individuals between May 2010 and May 2012 (see Table 1 in the Appendix), including large retailers, agricultural input suppliers (e.g. Growhow), knowledge providers (e.g. AB Sustain, Reaseheath College, industry consultants) and industry trade associations (e.g. Dairy UK, NFU). ${ }^{2}$ A core set of questions was asked to all interviewees concerning, for example, their role in reducing environmental impacts in the milk industry and factors that facilitated or hindered the adoption and diffusion of eco-innovations, probing both incremental and radical eco-innovations. We also asked more tailored questions, for example, to the large retailers about the nature of contracts with suppliers, about the ways in which the retailer interacted with the suppliers, and - following its emergence as a radical eco-innovation option - about anaerobic digestion. Most interviews lasted one hour with variations conditional upon interviewees' responses as well as the time interviewees were willing to spend. All interviews were recorded either in form of notes or (subject to agreement by the interviewee) transcribed from audio recordings. ${ }^{3}$ In addition, we had a large number of informal discussions with organisations from all stages of the milk CPS at various dairy industry events in 2011 and 2012 organised by Reaseheath College (a leading specialist land-based college) and Tesco. We did not aim for a representative sample; our past experience working in the industry meant a non-probabilistic sampling approach could be taken. We supplemented our primary material with an extensive review of current policy and industry initiatives and commentary on those initiatives.

We coded the secondary data, interview notes and recordings, grouping insights about the evolution of the milk CPS and the strategies of the focal organisation to stimulate both incremental and radical eco-innovation. To investigate theory elaboration we

\footnotetext{
2 It is difficult in practice to get interviews with farmers. We had informal conversations with a small number of farmers at industry events, and regard agricultural consultants such as AB Sustain, Lindsay and Delta, the trade association Dairy UK, and the farmers' union (NFU) as aggregators of farmer opinion.

${ }^{3}$ Note that one Interview 1 did not allow us to quote or attribute views to them directly. This interview provided an introduction to the topic and a useful reinforcement of what the researchers knew (and did not know) prior to the interview programme.
} 
emphasised abductive reasoning, modifying the general theory (innovation systems and sustainable/green supply chain management) to reconcile it with the contextual idiosyncrasies (Ketokivi and Choi, 2014). By taking an abductive reasoning approach we went 'back and forth' (Dubois and Gadde, 2002, p555) between theories and the empirical study before drawing final conclusions about the complementarities between the two approaches (Kovacs and Spens, 2005). To that end, the empirical insights inform sections 4.1 to 4.3 . In section 5 we compare and contrast the findings with the extant literature on both innovation systems and sustainable/green supply chains. Finally, we draw conclusions and call for further research in section 6.

\section{Analysis}

\subsection{Background: Co-evolution of the CPS and emergence of focal organisations}

It is not our intention to provide a comprehensive background to the milk CPS in the UK. ${ }^{4}$ We apply an innovation systems lens to summarise a more complex tale of actors, networks and institutions that shaped the milk CPS. Taking a long-view allows us to identify the cast of diverse actors (e.g. large dairy companies, government, large retailers), networks (e.g. transport, utilities, even the nature of the housing stock; contractual and relational links between organisations) and institutions (e.g. regulation, law; social practices and norms) that have co-evolved to structure the UK milk CPS. Atkins (2010) traces the transformation of what was a variable, perishable, organic fluid evolved to suit calves into a standardised food product sold to humans, loaded with technicity and artificially lengthened shelf life. Milk quality provides the focus of attention throughout Atkins' analysis, and for much of the 20th century, quality milk production was about guaranteeing milk composition (the fat content). The development of analytical tools, regulations and monitoring mechanisms upheld this quality requirement and helped shape the milk CPS. Farmers took seriously the composition of their cows' milk, breeding and feeding changed to suit the stateprescribed standard, and the national dairy herd was restructured (ibid.). The UK milk CPS remained remarkably stable for decades. The event that led to institutional change in the CPS was the dismantling of the Milk Marketing Board of England and Wales (a government-mandated monopsony) in 1994. Its dissolution meant a new

\footnotetext{
${ }^{4}$ We recommend interested readers start with Atkins (2010) historical account of milk.
} 
trajectory for milk consumption and production was needed (Dairy UK, 2010). The single UK-wide milk buyer and associated flat price were withdrawn, leaving a space for new contractual arrangements between buyers and sellers. Over a relatively short period of time, contractual arrangements for liquid milk evolved along a new trajectory, forged around supply-chain relationships controlled by large retailers. It was estimated that in 2012 around $60 \%$ of dairy farmers were signed up to a retailer contract.

Changes on the production side of the milk CPS were reinforced by changes on the consumption side. In the UK in the late 1970s, doorstep delivery brought milk to the vast majority (around $80 \%$ ) of households, propping up high volume sales and stable overall consumption levels at a time when other countries saw milk consumption decline (Blake, 1979). Following the change in supply chain arrangements, the difference between the price of doorstep-delivered milk and large retailer (supermarket) milk widened continually; supermarket milk was 10.9p per pint cheaper in 1993 (MDC, 2004) but 21.5p per pint cheaper by 2010 (Hawkins, 2011). Not surprisingly, by 1995 doorstep delivery accounted for just $45 \%$ of household milk purchases (MDC, 2004) and in 2012 doorstep delivery accounted for less than $5 \%$ of all liquid milk sales (Dairy UK, 2013). In 2012, over $70 \%$ of all fresh liquid milk was sold by the five largest large retailers.

In summary, what emerges from the historical secondary review and expert opinion from interviewees (Interview 4, 12,13) is that the lengthening shelf life of fresh milk, the emergence of own-label supply chains, changes in consumer purchasing habits and an increasing price advantage for retailers contributed critically to large retailers becoming focal in the milk CPS.

\subsection{Incremental eco-innovation in the milk CPS}

Over the last couple of decades, coinciding with the increased market power of the large retailers, an explicit acknowledgement emerged of the need to reduce environmental impacts whilst maintaining community cohesion and quality of life, and without compromising economic growth. This challenge is arguably more acute in the food industry given farmers assumed role as 'custodians of the countryside', the necessity of food production and current concerns over food security (Foster et al., 2007; Dairy Supply Chain Forum, 2008). Following an analysis of the interviews and 
secondary data, in the next two sub-sections we show two strategies used by the focal retailers to stimulate incremental eco-innovation in the milk CPS along existing trajectories of change.

\subsubsection{Procurement strategies}

In 2007, responding to pressure from farmers' representative groups and the media about the financial health of dairy farms, large UK retailers changed their procurement strategies and established long-term purchasing commitments offering higher farmgate prices to dairy farmers within their own dedicated supplier base (Dewick et al., 2010; Interviews 2, 3, 8, 11) 5 . These dedicated liquid milk suppliers received long(er) contracts and a premium for their milk in return for meeting large retailer demands for higher quality. The premium differed across large retailers and over time (e.g. one large retailer calculated premiums on an 'average cost plus' model: Interviews 13, 14), but was up to $15 \%$ above the average farm gate prices according to Walsh (2010). By 2007, what constituted 'quality' in milk production was now influenced by the large retailers and their corporate sustainability targets. Quality dimensions of the retailers' Code of Practice, which began with commitments to high standards of animal welfare, began to shift towards environmental targets such as lower carbon footprints, regionally-identified milk for local consumption and production (e.g. milk from Yorkshire, Scotland, Wales sold in regional supermarkets), often certified and endorsed by independent third parties (Interviews 6, 8, 12). Commitments to these quality characteristics were sought by large retailers in exchange for their long-term commitment to farmers. For example, interviews $(10,11,13,14,16)$ revealed that for farmers under contract to Tesco, receiving a price premium was conditional on a commitment to work with Promar, an independent agricultural consultant, to measure farmers' carbon footprints, and to work collaboratively to reduce carbon footprints in line with Tesco's strategic target of $20 \%$ reduction in supply chain greenhouse gas emissions by 2020. Over half of Tesco's farmers participated in this initiative, according to interviews $(13,14)$. In addition to price premiums, other retailers offered additional incentives, for example, access to "group purchase agreements" for milking

\footnotetext{
${ }^{5}$ Waitrose's group of dedicated milk suppliers was the first established; Tesco's Dairy Supply Group is the largest containing over 700 farmers (Interview 6, 11, 12, 13, 14). The groups are reported to have been established initially on geography (i.e. their location on a 'milk round'), which became important for some retailers wanting to segregate supply (Interviews $5,8,11,12,13$ ).
} 
parlour mats to prevent lameness and semen for breeding (Interview 8). These procurement strategies constituted one way in which the large retailers exercised their 'focal power' to work with farmers to incrementally reduce carbon emissions. Evidence suggests that the procurement strategies led to considerable strengthening of relationships in milk supply-chains: the strategies were mutually beneficial, supporting the long-term vision of the retailers, improving returns for the farmer and maintaining the market (Interviews 8, 11, 13, 14). As an agricultural manager at one of the large retailers argued (Interview 12): "the relationship between us [retailer and contracted dairy farmers] is now built on trust, whereas before it was an arms-length relationship on both sides". Evidence of strong relationships can be seen also in the Farmer Intentions Survey (Dairy Co., 2011), which reported dedicated-supply farmers had typically been on the same contract for longer, more were 'happy' with the buyer contract and none of those surveyed wanted to change buyer.

\subsubsection{Interactive buyer-supplier relationship strategies}

A long-recognised characteristic of farms is the wide difference between the performance (against many measures) of the 'best' and 'worst' farmers (Interview 8, $13,14)$. The uptake of best practice, such as the use of manure management plans or nutrient planning, is widely recognised as one route toward targeted reductions in environmental impacts in the milk CPS. Environmental best practice is also generally considered to improve economic performance, as the Environment Manager at Dairy UK, the industry trade association, observed: "Emergence of the low carbon agenda and its correlation with the resource efficiency agenda has brought with it a business focus to environmental activity" (Interview 2). Uptake of best practice in the farming community is characterised by the engagement of specialist advisors (Interview 4). Whilst this was historically the preserve of public agencies such as the National Institute for Research in Dairying (NIRD) and the Agricultural Development and Advisory Service (ADAS) (Atkins, 2010), the restructuring of the milk CPS around the supply chains of the large retailers led to a change in the provision of knowledge.

Over the last two decades, large retailers have developed supplier-improvement programmes for their dedicated suppliers (Interview 8, 10, 11, 17, 18). For example, Tesco established in 2007 a 'sustainable dairy group' (TSDG) for farmers that supply its own brand milk. Sharing of best practice among the TSDG is facilitated in a number 
of ways. There are regular (monthly) meetings between Tesco Dairy category technical staff and representatives of the TSDG, an annual conference with all farmers, regional farmer workshops, working groups tasked with exploring specific issues of interest to the group, and a 'Knowledge Hub' to share information and best practice about reducing environmental impacts. ${ }^{6}$

Moreover, TSDG members benefited directly from the Tesco funded 'centre of excellence' farm at the University of Liverpool where research was conducted into feeding, energy technologies and re-use/recycling. As part of the aforementioned new contracts, Promar, the independent agricultural consultant, not only measured over half of Tesco's suppliers' carbon footprints but also provided individual farms with feedback benchmarking performance against similar farms in the group. The initiative was followed up by advisory farmer workshops and written tailored advice about how to reduce carbon emissions. Sainsbury's, ASDA and the Cooperative are among the large retailers who acted in similar way to help their suppliers reduce environmental impacts (Interview 4, 8. This exemplifies a process in which large retailers assume responsibility to develop and diffuse knowledge in the CPS. It represents another important strategy of focal organisations to stimulate incremental eco-innovation.

Our findings show two strategies of the focal organisation to stimulate incremental eco-innovation along already established 'quality' and 'best practice' trajectories: first, by their procurement strategy; and, second, by their strategy to establish and maintain an interactive supplier-buyer relationship (e.g. sharing technical information, raising awareness and assisting their suppliers with the implementation of environmental programmes and production of materials, equipment or services that are less environmentally damaging). Whilst a number of interviewees raised concerns about the industry becoming divided into "have and have nots" (Interview 2; sentiments echoed in interviews 5 and 6), at a systems level there was some evidence of a positive consequence of the large retailer led strategies. For example, the trade association Dairy UK imitated the retailer initiatives, carbon-footprinting 416 farms to

\footnotetext{
${ }^{6}$ Interviewees noted that although it was difficult to demonstrate additionality from initiatives like the Knowledge Hub (i.e. identifying projects that would not have happened had it not been for sharing information on the knowledge hub), there was "plenty of anecdotes that say it's a great resource and that....it is providing a useful function for our suppliers" (Interview 14).
} 
identify causal links between actions and carbon reduction (Interview 2); processors contributed to trade association led schemes with the aim of exchanging knowledge between farmers (interview 2, 6).

\subsection{Radical eco-innovation in the milk CPS}

Radical eco-innovation, as noted in Section 2, often involves replacement of elements of the existing CPS by innovative ones that significantly reduce environmental impacts. This can inevitably involve conflict between incumbents and new entrants. Partly in consequence, radical eco-innovations are less common than incremental innovations. In the milk CPS, an innovation with significant potential to reduce GHG emissions is anaerobic digestion (AD). ${ }^{7}$ Cow excrement (manure) accumulates on farms when cows are indoors for milking or over winter. Since it contains both nitrogen and phosphorus, the resulting slurry has traditionally been spread on farmland, partly for fertilisation, partly for convenience. Poor storage and uncontrolled slurry spreading have been associated with pollution of the wider environment. Even when good practice is implemented, slurry storage and manure spreading contribute around $5 \%$ of the overall "carbon footprint" of liquid milk (Foster et al., 2007, Table 7, p.16). Feeding slurry into an anaerobic digester (usually in combination with higher energycontent feedstocks such as food waste or arable crops) represents an alternative method for handling this waste that avoids these emissions (Dairy Supply Chain Forum, 2008; Fantin et al., 2012). AD converts undigested material into "biogas" (mostly methane) which can be used as a fuel, potentially displacing fossil fuels in the wider energy supply system, leaving a more concentrated, nitrogen-rich liquid that can be used as fertiliser.

Interviews (e.g. interviews 7, 12, 13) and documents (Royal Agricultural Society of England, 2011) suggested that large retailers can exercise their focal power to stimulate the adoption and diffusion of AD technology, either via central or on-farm (decentralised) AD. The Royal Agricultural Society of England (2011), for example, notes the potential for large retailers to partially (or wholly) fund capital grants or

\footnotetext{
7 In addition to potentially reducing significantly the environmental impacts of the production stage of the milk CPS, AD may also be considered radical because requires farmers [or other organisations] to learn new (chemical) competencies, and because it requires new organisational arrangements (Mylan et al., 2015).
} 
provide rolling loans with preferential terms. Access to capital can be difficult for technology characterised as new and high risk and supplied by firms with little financial security. Even if access to capital is facilitated, interviewees (e.g. interviews 2, 7, 12, 13) and documents (e.g. Royal Agricultural Society of England, 2011; DEFRA, 2012) referred to significant obstacles associated with the structure of the CPS. For example, for a viable centralised AD plant, location is critical: on the demand side, sourcing large quantities of manure (and other inputs), and on the supply side, the availability of uses for heat and power produced. Regulatory barriers complicate further these location issues, for example uncertain revenue streams (e.g. feed-in tariffs), the need to comply with waste regulations (e.g. HM Government, 2011) ${ }^{8}$, gas composition standards and planning conditions. Interviews (e.g. Interviews 12, 13) and documents (DEFRA, 2012) suggested that the barriers stemming from planning and waste regulations have proved too high a hurdle to overcome for large retailer-backed centralised $A D$ initiatives.

Emerging from the interviews (Interviews 2, 6, 7), another strategy suggested for the focal retailers was to use procurement strategies to contract with large scale, diversified farmers with on-farm (decentralised) AD. However, this approach comes up against significant systemic barriers, albeit different from those hindering centralised AD. Rural Futures (2010) estimated that on-farm AD would be viable only for a farm with a 300-head dairy herd and producing around 2000 tonnes of maize silage per year. Although the average herd size in the UK has doubled in the last twenty years, it was only 125-head in 2012 (Dairy.Co ${ }^{9}$ ). Moreover, such a procurement strategy would be in tension with public opinion, which associates concentrated farming with poor cow welfare (e.g. increased mastitis, increased lameness and increased infertility) and favours outdoor grazing (Interviews 2, 13). Concentration also disfavours both the multiplicity of farm units that many say characterises the UK landscape and the maintenance of non-productive areas that nurture biodiversity; retention of traditional field boundaries and implementation of wide field boundaries (as required in the "LEAF Marque" agri-environment scheme, LEAF 2014) inevitably uses space that could be given over to grazing or crops. Given this, and the public

\footnotetext{
8 http://www.legislation.gov.uk/uksi/2011/881/pdfs/uksi_20110881_en.pdf, last accessed July 2017 ${ }^{9}$ Historical average herd numbers for the UK are available at https://dairy.ahdb.org.uk/resourceslibrary/market-information/farming-data/average-herd-size/\#.WTVFsILMxsM, last accessed June 2017.
} 
relations sensitivity of the large retailers, widespread implementation of a strategy to encourage large scale diversified dairy farming would likely need to be accompanied by a considerable consumer education effort to gain acceptance and maintain public trust in the milk CPS (Interview 8).

\section{Discussion}

In section 4, we show how the co-evolution of the CPS has accompanied an emerging focal role for one type of organisation. Beginning with the dissolution of the milk marketing board (a monopsony buyer of milk), we show how the focal retailers took over the mantle of stimulating innovation, in our case eco-innovation, usurping other organisations such as public agencies and dairy processors. Changes of leadership are characteristic of innovation system studies, often occurring as a result of a technological or regulatory or social change. A process of wider change begins, spearheaded by specific organisations, often in collaboration with others. For Faber and Hoppe (2012), for example, in their snap shot of energy efficient technologies in the Dutch housing sector, it was the project developers and construction firms that were the 'primary agents' of change, interacting with the other stakeholders in the SSI. Where change is not happening, a lack of leadership and collaboration is sometimes a dominant cause, such as in Alphen et al's (2010) and Lai et al's (2012) analysis of the carbon capture and storage TIS. Innovation systems approaches offer some insight into the activities of core/key/primary actors, but because the unit of analysis in these systems perspectives is not a single (type of) organisation, the strategies to stimulate eco-innovation at an organisational level are not scrutinised.

We argue that analysing the strategies of organisations allows us to understand better the dynamics at a systems level, and vice versa. With this approach, we contribute to the eco-innovation literature by exploring strategies for incremental and radical ecoinnovation in the context of a consumption and production system. Our findings reveal how the focal large retailers deploy their resources and competencies in purchasing and supply chain management to stimulate incremental eco-innovation upstream along established 'quality' and 'best practice' trajectories. We show how the focal organisation has established groups of dedicated suppliers and then driven incremental eco-innovation (in our case, to reduce carbon emissions) at the point of high environmental impact (in our case, the production stage) through technical 
requirements within new contractual arrangements with suppliers (in our case, farmers). These arrangements are evidence of Roscoe et al.'s (2016) proposition concerning incremental eco-innovations stemming from "strong ties with strategic suppliers" (p.1954). Our findings extend Roscoe's et al.'s (2016) model by revealing how focal organisations work within and beyond the 'tight' supplier network, engaging interactively with stakeholders in the wider CPS: investing in knowledge creation (in our case, for example, through links with universities and veterinary organisations), and developing information sharing and knowledge integration opportunities (in our case, for example, both virtual and in-person knowledge exchange opportunities) to promote incremental eco-innovation. These strategies are underpinned by capabilities of the focal organisation. For example, the procurement strategies would not work without the integration of new partners into the supply chain (in our case, independent consultants like Promar) to help develop suppliers in a way that enables them to contribute positively toward the focal organisation's strategic targets (in our case, Tesco's target of a $20 \%$ reduction in supply chain greenhouse gas emissions by 2020). Benefits are shared with the suppliers to recognise their contribution to the strategic long-term commitment of the focal organisation (in our case, predominantly through higher unit payments). The knowledge creation and dissemination strategies would not work without the capabilities of the focal organisation to assess what knowledge the CPS has and needs and to facilitate knowledge development and diffusion (in our case, for example, increasing knowledge by sponsoring research and development at universities, and providing training, workshops and virtual spaces to disseminate best practice). Our findings also show that focal organisations need to demonstrate compliance by measuring and evaluating the performance of supply chains (in our case, through key performance indicators and effective audit of farmers).

These capabilities align with those found by Beske et al. (2013) in their extensive review on supply chain management practices in the food industry. For Beske et al. (2013), organisations managing their supply chain in a sustainable manner can engage in practices that enhance relationships with suppliers (e.g. through shared strategic commitments, continuity of relationships) and wider stakeholders, and improve the flow of information and of goods and services (e.g. through collaboration and risk management). Beske et al. (2013) go on to argue that these practices are based on capabilities of partner development, supply chain reconceptualization and 
co-evolution, knowledge management and reflexive control. We see all these practices and capabilities in the strategies of the focal organisation in our case. Where our approach contributes to the sustainable/green supply chain literature is by offering a more critical lens through which to consider the likelihood of strategies having their intended outcome: whether the change will be incremental or radical, and whether it will ultimately contribute to a more sustainable CPS. In our case, whilst we see these strategies working well for stimulating incremental eco-innovation (change along the grain of the CPS), they work less well for stimulating radical eco-innovation (where change goes against the grain and face significant resistance from the current CPS). In our case, on the production side, barriers connected both to the structure of the industry, regulation and insufficient financial incentives; on the consumption side, barriers associated with public perceptions of the industry. We find that the diffusion of radical eco-innovation would be facilitated by CPS reconfiguration, but that there is no evidence of the focal organisation supporting this at present, or of other actors entering the CPS to lead change. The implication is that some eco-innovation pathways, that could potentially contribute to a more sustainable CPS, are held up by the existing CPS, limiting the effect of focal organisation strategies. This echoes Hellstrom (2007) and Carrillo-Hermosilla et al. (2010), the latter of whom asserts that "eco-innovations, particularly when they are radical and require techno-institutional system-level changes, are difficult to achieve because the prevailing system may act as a barrier to the creation and diffusion of a new system" (p1078). So, whilst our findings are also consistent with Van Bommel's (2011) and Roscoe et al's (2016) implicit and explicit (respectively) conceptualisations of what focal organisation strategies may promote radical eco-innovation - developing new supply network structures in the case of von Bommel (2011); scanning and securing eco-innovations by bridging "structural holes between existing and new industrial networks" in the case of Roscoe et al. (2016, p.1956) - our combined approach sheds some light on how the provenance of a CPS affects whether these strategies are likely to lead to radical change. Our analysis suggests that the ability of a focal organisation to affect the role and direction of eco-innovation trajectories is inextricably linked with the characteristics of the CPS within which it occupies a unique position.

The implication for the sustainable/green supply chain literature, especially the merging strand that takes a wider networks perspective (e.g. van Bommel, 2011; 
Roscoe et al., 2016), is that one should be cautious in interpreting the strategies of focal organisations as necessarily contributing to more sustainable CPS, as they may only serve part of the CPS. Our case shows that the strategies followed by the focal organisation support eco-innovation within their own supply chains, neglecting the many suppliers in the CPS not tied to large retailers. The effectiveness of focal organisations in raising the performance of the whole CPS, as opposed to their own supply chain, is beyond their control and therefore in doubt. That is not to say a focal organisation cannot orchestrate system wide change, but that its ability to do so depends on mobilising the support of others. In our case, for example, we show how the retailer led strategies inspired imitation by the wider industry, led by the trade association, but along incremental eco-innovation trajectories.

This adds another layer of uncertainty to the on-going discourse about what constitutes an eco-innovation. Some argue that if an innovation has a demonstrable but unintended positive economic and environmental benefit, it can be classed as an eco-innovation. For others, intention matters, and eco-innovation must stem from a motivation to add value and improve environmental performance. As our case shows, even when there is intention, demonstrating a net environmental benefit is not always straightforward, especially at a systems level. The literature already acknowledges that environmental improvements are tricky to ascertain because of the 'rebound effect', 'green paradox' and 'crowding out' effect of eco-innovation over a product's life cycle (van den Bergh, 2013; Sica, 2016). To that list, we can add the uncertainty associated with the reach of focal organisation strategies.

The limitations of a case study are usually considered to be the generalisability of the findings. Whilst our paper looked at the milk CPS, a case chosen because of its comparatively high environmental impacts and because it is demonstrably in the vanguard of focal organisation engagement strategies to stimulate eco-innovation, it is not unique. We argue that the case illustrates a broader phenomenon. In that regard, the paper also has a practical utility as it begs the question of whether policy makers are correct to rely on focal organisations to chart a path toward more sustainable CPS. From an environmental perspective, the UK milk CPS shares similar life cycle impacts with a large number of other food CPS where the greatest impacts are associated with upstream primary production/ processing, or downstream at the consumption stage 
(Foster et al., 2006). Although the environmental impacts in these CPS are not principally associated with the retailing stage itself, or with inbound transport of products to large retailers, retailers are often able to influence environmental performance improvement at the locus of greatest environmental impact within a CPS (Green et al., 1998; Huber, 2008; Lowe and Gereffi, 2009; Rieple and Singh, 2010; Glover et al., 2014). The retailers' influence stems from their position in the CPS and a combination of buying power and detailed knowledge of the purchasing patterns of final consumers. This explains why environmental policy makers have endowed their hopes in retailers exerting their influence to bring eco-innovation to remote CPS environmental hotspots. Our paper, combining evolutionary and strategic insights, offers a cautionary note for policymakers: relying on improvement by current focal organisations risks entrenching existing structures and power relationships, which may inhibit the emergence of new structures that could be more sustainable in the long run.

\section{Conclusions}

Without more sustainable CPS, 2030 UN goals for sustainable development will be missed. We know that eco-innovation, especially radical eco-innovation, is important for sustainable CPS. We also know that collaboration is a significant driver of ecoinnovation. Innovation systems approaches have often been used as a lens to study sustainable change at a bounded systems level. Sustainable/green supply chain management approaches offer insights into the firm level strategies of individual actors. The aim of this paper has been to explore the role of 'focal organisations' deemed 'focal' by virtue of their buying power and position in the CPS - in stimulating eco-innovation at the locus of greatest environmental impacts within a CPS. We argue that to understand better the strategies of focal organisations to stimulate ecoinnovation and to bring long-term reductions in environmental impacts, it is important to analyse their activities using both evolutionary insights from sustainable innovation systems and strategic insights from the sustainable/green supply chain management literature. In meeting this aim, we address calls in the literature for more inter-level studies (Boons and Wagner, 2009) and make a theoretical contribution to the literature. Ridder et al (2012) argue that "case study findings can provide a theoretical contribution if they challenge, change or fundamentally advance our understanding of a phenomenon or initiate new theory". Our paper seeks to stimulate a dialogue about 
the merit of bridging the two theoretical domains (Le-Pine and Wilcox-King, 2010). Our paper also has practical utility, raising questions for policy makers wanting to chart a path toward more sustainable CPS. We call for further studies exploring the role of focal organisations in more sustainable CPS to employ both theoretical lenses to improve our understanding of the connections between the two levels. Future studies attempting to understand the rate and direction of eco-innovation in a CPS should account for the role of focal organisations, exploring how their power has evolved with respect to the characteristics of the CPS (actors, networks, institutions) and the likelihood that their strategies will stimulate incremental and radical eco-innovation, and to what extent they can orchestrate system-wide sustainable change.

\section{Acknowledgements}

Special thanks to Professor Jonatan Pinkse for his critical comments that helped improve the paper.

\section{Funding}

This work was supported by the Sustainable Consumption Institute (www.sci.manchester.ac.uk). The sponsor had no involvement in the study design, in the collection, analysis and interpretation of data, in the writing of the report and in the decision to submit the article for publication.

\section{References}

Atkins P., 2010, Liquid materialities: a history of milk, science and the law. Farnham: Ashgate

Beske, P., Land, A. and Seuring, S., 2013, Sustainable supply chain management practices and dynamic capabilities in the food industry: a critical analysis of the literature, International Journal of Production Economics, http://dx.doi.org/10.1016/j.ijpe.2013.12.026

Blake F.G.B., 1979, Storage and transport of Pasteurized Milk, Journal of the Society of Dairy Technology, 32, 72-77

Boons, F. and Wagner, M., 2009, Assessing the relationship between economic and ecological performance: Distinguishing system levels and the role of innovation, Ecological Economics, 68, 1908-1914, doi:10.1016/j.ecolecon.2009.02.012 
Bossle, M.B., Dutra de Barcellos, M., Vieira, L.M., Sauve, L., 2016, The drivers for adoption of eco-innovation, Journal of Cleaner Production, 113, 861-872, http://dx.doi.org/10.1016/j.jclepro.2015.11.033

Cainelli, G., De Marchi, V., Grandinetti, R., 2015, Does the development of environmental innovation require different resources? Evidence from Spanish manufacturing firms, Journal of Cleaner Production, 94, 211-220, http://dx.doi.org/10.1016/j.jclepro.2015.02.008

Carlsson B. and Skankiewicz R., 1991, On the nature, function and composition of technological systems, Journal of Evolutionary Economics, 1: 93-118

Carrillo-Hermosilla, J. del Río P. and Könnölä, 2010, Diversity of eco-innovations: Reflections from selected case studies, Journal of Cleaner Production, 18, 1073-1083

Carter, R.C. and Rogers, D.S., (2008), A framework of sustainable supply chain management: moving toward new theory, International Journal of Physical Distribution \& Logistics Management, 38 (5): 360-387, doi: 10.1108/09600030810882816

Coenan L. and Diaz Lopez FJ, 2011, Comparing systems approaches to innovation and technological change for sustainable and competitive economies: an explorative study into conceptual commonalities, differences and complementarities, Journal of Cleaner Production, 18, 1149-1160

Coriat, B. \& Weinstein, O. (2002). Organizations, firms and institutions in the generation of innovation. Research Policy, 31 (2): 273-290.

Dairy Supply Chain Forum, 2008, UK Milk Roadmap, Available at http://webarchive.nationalarchives.gov.uk/20130402151656/http://archive.defra.gov. uk/environment/business/products/roadmaps/documents/milk-roadmap.pdf, last accessed January 2017

Dairy UK, 2010, The White Paper: A Report on the UK Dairy Industry, Dairy UK: London

Dairy UK, 2013, The White Paper 2013: A Guide to the UK Dairy Industry, Dairy UK: London

Dairy Co, 2011, Dairy Supply Chain Margins 2010/11, Available at http://www.dairyco.net/media/480202/dairy supply 2011 web.pdf, last accessed January 2017

De Marchi, V., 2012, Environmental innovation and R\&D cooperation: Empirical evidence from Spanish manufacturing firms, Research Policy, 41 (3), 614-623

Dewick, P., Foster, C., and Green, K., (2007), "Technological change and the environmental impacts of food production and consumption: the case of the UK yoghurt industry", Journal of Industrial Ecology, 11, 3. 133-146 
Dewick, P., Foster, C. and Webster, S. (2010), "Facilitating a more sustainable food and farming sector in the UK" in Tischner, U. et al. (eds), System Innovation for Sustainability 3: Case Studies in Sustainable Consumption and Production - Food and Agriculture, Greenleaf Publishing: Sheffield

DEFRA, 2012, Progress towards a sustainable future for livestock farming, Available at http://www.defra.gov.uk/publications/files/pb13756-sustainable-livestock.pdf, last accessed January 2017

Dubois, A. and Gadde, L.E., (2002), Systematic combining: an abductive approach to case research, Journal of Business Research, 55: 553-560

Eide, M.H., 2002, Life cycle assessment of industrial milk production, International Journal of LCA, 7 (2), 115-126

Eisenhardt, K, 1989, Building theories from case re- search. Academy of Management Review, 14: 532- 550.

Evans R. 2011. Case Study Method in Sustainability Research. In Alex Franklin, Paul Blyton (eds.), Researching sustainability. A guide to social science methods, practice, and engagement, London: Earthscan, 54-70.

Faber, A. and Hoppe, T., 2012, Co-constructing a sustainable built environment in the Netherlands-Dynamics and opportunities in an environmental sectoral innovation system, Energy Policy, 52, pp.628-638, DOI: 10.1016/j.enpol.2012.10.022

Fantin, V., Buttol, P., Pergreffi, R. and Masoni, P., 2012, Life cycle assessment of Italian high quality milk production. A comparison with an EPD study, Journal of Cleaner Production, 28, pp.150-159

Flanagan, K. et al. (2011). Reconceptualising the "policy mix" for innovation. Research Policy, 40 (5), 702-713

Forum for the Future, 2012, Dairy 2020: A vision and framework for a sustainable UK dairy industry, Available at http://www.forumforthefuture.org/project/dairy2020/overview, last accessed January 2017

Foster, C., Green, K., Bleda, M., Dewick, P., Evans, B., Mylan, J., Randles, S., (2006), Environmental impacts of food production and consumption (widely known as the 'Shopping Trolley' report), Department of Environment, Food and Rural Affairs: London, available at http://randd.defra.gov.uk/Document.aspx?Document=EV02007_4601_FRP.pdf, last accessed July 2017

Foster, C., Audsley, E., Williams, A. Webster, S., Dewick, P. and Green. K., (2007), The environmental, social and economic impacts associated with liquid milk consumption in the UK and its production, Department of Environment, Food and Rural Affairs: London, available at 
http://www.defra.gov.uk/publications/2011/09/22/pb13644-milk-impacts/,

last accessed July 2017

Geels, F.W. and Schot, J., 2007, Typology of sociotechnical transition pathways, Research Policy, 36:3, 399-417

George AL. and Bennett, A., 2005, Case studies and theory development in the social sciences. Cambridge, Mass: MIT Press.

Gereffi, G., 1994, The Organization of Buyer-Driven Global Commodity Chains. In: Gereffi, G. and Korzeniewicz, M. (eds.) Commodity chains and global capitalism. Greenwood Press, Westport, CT, pp. 95- 122.

Gereffi, G. Humphrey J. and Sturgeon T., 2005, The governance of global value chains, Review of International Political Economy, 12: 78-104

Ghisetti, C., and Pontoni, F., 2015, Investigating policy and R\&D effects on environmental innovation: A meta-analysis, Ecological Economics, 118,57-66, http://dx.doi.org/10.1016/j.ecolecon.2015.07.009

Glover, J.L., Champion, D., Daniels, K.J., and Dainty, AJD, 2014, An institutional theory perspective on sustainable practices across the dairy supply chain, International Journal of Production Economics, http://dx.doi.org/10.1016/j.ijpe.2013.12.027

Green, K. Morton, B. and New SJ, 1998, Green Purchasing and Supply Policies: Do They Improve Companies Environmental Performance? Supply Chain Management: An International Journal, 3: 15-22.

Haley, B., 2014, Promoting low-carbon transitions from a two-world regime: Hydro and wind in Québec, Canada, Energy Policy, DOI: 10.1016/j.enpol.2014.05.015

Hansen, E.U. and Nygaard, I., 2014, Sustainable energy transitions in emerging economies: The formation of a palm oil biomass waste-to-energy niche in Malaysia 1990-2011, Energy Policy 66, pp. 666-676, DOI: 10.1016/j.enpol.2013.11.028

Hawkins G. 2011. Dairy industry in the UK: statistics. available at http://www.dairyco.net/datum/consumer/liquid-milk-market/liquid-milk-market.aspx, last accessed January 2017

Hellstrom, T., 2007, Dimensions of Environmentally Sustainable Innovation: the Structure of Eco-Innovation Concepts, Sustainable Development , 15, 148-159, DOI: $10.1002 / \mathrm{sd} .309$

Henriques, I. and Sharma, S., 2005, Pathways of stakeholder influence in the Canadian forestry industry, Business Strategy and the Environment, 14, 384-398

Horbach, J., Oltra, V. and Belin, J., 2013, Determinants and specificities of ecoinnovations compared to other innovations - an econometric analysis for the French 
and German industry based on the Community Innovation Survey, Industry and Innovation, 20:6, 523-543

HM Government (2011), The Animal By-Products (Enforcement) (England) Regulations 2011, available at http://www.legislation.gov.uk/uksi/2011/881/pdfs/uksi_20110881_en.pdf, last accessed July 2017

Huber J., 2008, Technological environmental innovations in a chain-analytical and life-cycle-analytical perspective, Journal of Cleaner Production, 16: 1980-1986

Ketokivi, M. and Choi, T., (2014), Renaissance of case research as a scientific method, Journal of Operations Management, 32: 232-240

King, N., 2006, Using Interviews in Qualitative Research. In: Cassell, C. and Symon, G. (eds.) Essential guide to qualitative methods in organizational research, Reprint. Sage Publ., London, 11-22.

Kiss, B., González Manchón, C., Neij., L., 2013, The role of policy instruments in supporting the development of mineral wool insulation in Germany, Sweden and the United Kingdom, Journal of Cleaner Production, 48, 187-199, http://dx.doi.org/10.1016/j.jclepro.2012.12.016

Kovács, G. and Spens, K.M., (2005), Abductive reasoning in logistics research, International Journal of Physical Distribution \& Logistics Management, 35 (2): 132144, doi: 10.1108/09600030510590318

Lai, X., Ye, Z., Xu, Z., Holmes, M.H. and Lambright, W.H, 2012, Carbon capture and sequestration (CCS) technological innovation system in China: Structure, function evaluation and policy implication, Energy Policy, 50: 635-646.

LEAF, 2014, LEAF Marque Global Standard Version 12.0, 1st October 2014, Linking Environment and Farming.

Lebel, L. and Lorek, S., 2008, Enabling Sustainable Production-Consumption Systems, Annual Review of Environment and Resources, 33 (1), 241-275.

LePine, J. A. and A. Wilcox-King, (2010), 'Editors' comments: developing novel theoretical insight from reviews of existing theory and research', Academy of Management Review, 35: 506-509.

Leppelt, T.; Forest, K.; Reuter, C.; Hartmann, E., 2011, Sustainability management beyond organizational boundaries-sustainable supplier relationship management in the chemical industry, Journal of cleaner production 56, 94-102, doi: 10.1016/j.jclepro.2011.10.011

Lowe M. and Gereffi G., 2009, A Value Chain Analysis of the U.S. Beef and Dairy Industries, Center on Globalization, Governance and Competitiveness, Duke 
University,

http://www.researchgate.net/publication/237616007 A Value Chain Analysis of th e U.S. Beef and Dairy Industries Report Prepared for Environmental Defense Fund, last accessed January 2017

Malerba, F., 2002, Sectoral systems of innovation and production, Research Policy. 31: $247-264$

Milk Development Council (MDC), 2004, Dairy Facts and Figures 2003, Milk Development Council: London

Mylan. J., Geels, F.W. Gee, S. McMeekin, A., and Foster, C., (2015), Eco-innovation and retailers in milk, beef and bread chains: enriching environmental supply chain management with insights from innovation studies, Journal of Cleaner Production, 107: $20-30$

Product Sustainability Forum (PSF), 2013, An initial assessment of the environmental impact of grocery products, Available at http://www.wrap.org.uk/priorityproducts, last accessed January 2017

Rennings, K., 2000, Redefining innovation - eco-innovation research and the contribution from ecological economics, Ecological Economics, 32, 319-332

Ridder, H. G., Hoon, C., \& McCandless Baluch, A., 2012, Entering a dialogue: Positioning case study findings towards theory, British Journal of Management, 25(2), 373-387.

Rieple, A. and Singh, R., 2010, A value chain analysis of the organic cotton industry: The case of UK retailers and Indian suppliers, Ecological Economics, 69, 2292-2302, doi:10.1016/j.ecolecon.2010.06.025

Roscoe, S., Cousins, P.D., Lamming, R.C., 2016, Developing eco-innovations: a three-stage typology of supply networks, Journal of Cleaner Production, 112, 19481959, http://dx.doi.org/10.1016/j.jclepro.2015.06.125

Royal Agricultural Society of England, 2011, A Review of Anaerobic Digestion Plants on UK Farms - Barriers, Benefits and Case Studies, Available at http://www.freenergy.co.uk/pdf/RASE-On-Farm-AD-Review.pdf, Last accessed January 2017

Rural Futures, 2010, Economic Viability of Farm Scale AD Biogas Production across Cheshire and Warrington, Rural Futures (North West) Ltd.

Sica, E., 2016, Economic theories of eco-innovations: a comparison between the neoclassical and evolutionary approaches, International Journal of Innovation and Sustainable Development, 10, 1, 87-102.

Suering, S. and Muller, M., (2008), From a literature review to a conceptual framework for sustainable supply chain management, Journal of Cleaner Production, 16: 1699_ 1710 
Triguero, A., Moreno-Mondejar, L., and Davia, M.A., 2013, Drivers of different types of eco-innovation in European SMEs, Ecological Economics, 92, 25-33, http://dx.doi.org/10.1016/j.ecolecon.2013.04.009

United Nations, 2015, Transforming our world: the 2030 agenda for sustainable development, A/RES/70/1, available at https://sustainabledevelopment.un.org/content/documents/21252030\%20Agenda\%2 0for\%20Sustainable\%20Development\%20web.pdf, last accessed January 2017

van Alphen, K., Hekkert, M.P., and Turkenburg, W.C., 2010, Accelerating the Deployment of Carbon Capture and Storage Technologies by Strengthening the Innovation System, International Journal of Greenhouse Gas Control, 4: 396-409.

van Bommel HWM, 2011, A conceptual framework for analysing sustainability strategies in industrial supply networks from an innovation perspective, Journal of Cleaner Production, 19: 895-904

Vaughan S., 2011., Elite and Elite-lite Interviewing. Managing our Industrial Legacy. In Alex Franklin, Paul Blyton (eds.) Researching sustainability. A guide to social science methods, practice, and engagement, London: Earthscan, 105-119.

Vergragt, P., Akenji, L., Dewick, P., (2013), Sustainable Production, Consumption, and Livelihoods: Global and Regional Research Perspectives, Journal of Cleaner Production, http://dx.doi.org/10.1016/j.jclepro.2013.09.028, 63, 15. 1-13

Van den Bergh, C.J.M., Truffer, B. and Kallisa, G., 2011, Environmental innovation and societal transitions: Introduction and overview, Environmental Innovation and Societal Transitions, 1, 1-23, doi:10.1016/j.eist.2011.04.010

Van den Bergh, J.C.J.M., 2013, Environmental and climate innovation: Limitations, policies and prices, Technological Forecasting \& Social Change, 80, 11-23, http://dx.doi.org/10.1016/j.techfore.2012.08.004

Vurro, C., Russo, A. and Perrini, F., 2009, Shaping sustainable Value Chains: network determinants of supply chain governance models, Journal of Business Ethics, 90, 607621

Wagner, M. and Llerena, P., 2011, Eco-innovation through integration, regulation and cooperation: comparative insights from case studies in three manufacturing sectors, Industry and Innovation, 18:8, 747-764

Walsh H., 2010, Long-term milk supply deals unveiled, Farmers' Guardian, online edition, http://www.farmersguardian.com/home/business/business-news/long-termmilk-supply-deals-unveiled/34650.article, last accessed October 2014

Yin, R., (2010), Case study research: Design and methods, 4th edition. Thousand Oaks, California: Sage

J. Yuan, Y. Xu, Z. Hu, 2012, Delivering power system transition in China, Energy Policy, 50, 751-772 


\section{Appendix}

\section{Table 1: Interviews}

\begin{tabular}{|c|c|c|c|c|}
\hline $\begin{array}{l}\text { Organisation } \\
\text { Type }\end{array}$ & $\begin{array}{l}\text { Organisation } \\
\text { Name }\end{array}$ & Position of interviewee within organisation & $\begin{array}{l}\text { Date of } \\
\text { interview }\end{array}$ & $\begin{array}{l}\text { Interview } \\
\text { number } \\
\text { (referenced } \\
\text { in text) }\end{array}$ \\
\hline $\begin{array}{l}\text { Representative } \\
\text { group }\end{array}$ & $\begin{array}{l}\text { Milk Roadmap } \\
\text { Task Force }\end{array}$ & $\begin{array}{l}\text { Taskforce Chairman } \\
\text { Taskforce representative of the Department of Environment, } \\
\text { Food and Rural Affairs } \\
\text { Taskforce representative of producer interests }\end{array}$ & 10 May 2010 & 1 \\
\hline $\begin{array}{l}\text { Trade } \\
\text { association }\end{array}$ & Dairy UK & Environment Manager & 12 May 2010 & 2 \\
\hline $\begin{array}{l}\text { Agricultural } \\
\text { consultant }\end{array}$ & AB Sustain & Commercial Director & 22 Feb 2011 & 3 \\
\hline $\begin{array}{l}\text { Agricultural } \\
\text { input supplier }\end{array}$ & Growhow UK & $\begin{array}{l}\text { Public Affairs Director (and agronomist) } \\
\text { Grassland Specialist }\end{array}$ & $\begin{array}{l}2 \text { March } 2011 \\
\text { (and site visit) }\end{array}$ & 4 \\
\hline $\begin{array}{l}\text { Agro- } \\
\text { economics } \\
\text { consultancy }\end{array}$ & $\begin{array}{l}\text { Delta } \\
\text { Innovation }\end{array}$ & Managing Director & 25 March 2010 & 5 \\
\hline $\begin{array}{l}\text { Dairy industry } \\
\text { consultancy }\end{array}$ & $\begin{array}{l}\text { Brian Lindsay } \\
\text { Consulting }\end{array}$ & Principal & 20 April 2010 & 6 \\
\hline $\begin{array}{l}\text { Agricultural } \\
\text { college and AD } \\
\text { development } \\
\text { programme }\end{array}$ & $\begin{array}{l}\text { Reaseheath } \\
\text { College } \\
\text { Enterprise Hub }\end{array}$ & Knowledge Transfer Manager & $\begin{array}{l}16 \text { Nov } 2010 \\
\text { (and site visit) }\end{array}$ & 7 \\
\hline Retailer & ASDA & $\begin{array}{l}\text { Dairy category manager } \\
\text { Head of sustainable sourcing }\end{array}$ & 14 Feb 2011 & 8 \\
\hline $\begin{array}{l}\text { Industry } \\
\text { association }\end{array}$ & NFU & $\begin{array}{l}\text { Climate Change Advisor } \\
\text { Livestock Advisor at NFU }\end{array}$ & 18 Feb 2011 & 9 \\
\hline
\end{tabular}




\begin{tabular}{|l|l|l|l|l|}
\hline & & & & \\
\hline Retailer & Tesco & Climate Change Manager & 18 Feb 2011 & 10 \\
& & Agricultural Manager & 26 Sept 2011 & 11 \\
& & Dairy Category Technical Manager & 6 March 2012 & 12 \\
& & Dairy Category Buying Manager & 25 April 2012 & 13 \\
& & Head of Sustainable Supply Chain Carbon Reduction & 6 March 2012 & 14 \\
& & Climate Change Manager & 3 April 2012 & 15 \\
& & Climate Change Manager & 3 April 2012 & 16 \\
& & Dairy Category Junior Buyer & 11 May 2012 & 17 \\
& & Dairy Category Junior Technical & 11 May 2012 & 18 \\
\end{tabular}


